\title{
Analisis Dan Perancangan Sistem Informasi Penjualan Rumah Berbasis Web Pada PT Indah Cemani Raya Balaraja
}

\author{
Imam Aji Santoso ${ }^{1}$, Rina Agustina ${ }^{2}$, Fauziah Nur Akmalia ${ }^{3}$ \\ ${ }^{1}$ Program Studi Akuntansi Universitas Raharja, ${ }^{2,3}$ Program Studi Sistem Informasi Universitas \\ Raharja \\ Email: ${ }^{1}$ imam.aji@ raharja.info,*22Rina Agustina@ raharja.info, ${ }^{3}$ fauziah.nur@ raharja.info
}

\begin{abstract}
Abstrak
Sistem yang digunakan oleh perusahaan dalam menangani pencatatan dan penjualan produk rumah masih dilakukan secara manual sehingga menghambat kinerja perusahaan. Dalam artian, sebuah perusahaan merupakan satu kesatuan sistem yang saling mempengaruhi satu sama lain untuk mencapai tujuan tertentu. Dalam sistem usulan yang penulis rancang dapat menyelesaikan permasalahan tersebut sekaligus memberikan informasi penjualan rumah dengan cepat. Seperti misalnya, kebutuhan pengolahan data yang semakin meningkat, aturan pengolahan data yang semakin bervariasi, aturan dari dalam atau luar perusahaan, dapat digunakan sebagai indikator adanya permasalahan. Maka PT Indah Cemani Raya, Balaraja melakukan perancangan aplikasi untuk sistem informasi perumahan Balaraja berbasis web. Sistem ini digunakan untuk memudahkan dalam proses penjualan, promosi dan informasi detail tentang perumahan Balaraja, dimana marketing dapat memasukan listing rumah yang dititipkan oleh customer kesitus web PT Indah Cemani Raya, Balaraja untuk dipasarkan, dan adanya sebuah aplikasi untuk mengaktifkan listingan penjualan rumah yang telah diinput oleh marketing kesitus web. Laporan yang dihasilkan berupa laporan data rumah, laporan pembeli rumah, laporan pemasaran rumah, laporan pembayaran secara periodik, spesifikasi rumah dan simulasi kredit. Saat ini belum adanya sistem untuk memudahkan pelanggan dalam melihat produk perumahaan dan juga melakukan pemesanan tanpa harus datang ke lokasi.Tujuan dari penulisan jurnal ini adalah untuk menganalisis dan merancang suatu sistem penjualan pada PT Indah Cemani Raya, Balaraja. Sehingga dapat membantu pihak-pihak yang terkait dalam proses pendataan terutama dalam proses penjualan rumah. PT Indah Cemani Raya, Balaraja adalah perusahaan swata yang bergerak dalam bisnis properti, khususnya dibidang penjualan pembangunan perumahan (developer) yang membantu pemerintahan dalam meningkatkan pembangunan ekonomi nasional.
\end{abstract}

Kata kunci : Sistem Informasi, Laporan Perusahaan, Penjualan Rumah.

\begin{abstract}
The system used by the company in handling the recording and sale of home products is still done manually as to hamper the company's performance. In a sense, a company is a unified system that influences one another to achieve certain goals. In the proposed system that the author designed to solve these problems while providing information on home sales quickly. For example, data processing needs are increasing, data processing rules are increasingly varied, rules from within or outside the company, can be used as indicators of problems. So PT Indah Cemani Raya, Balaraja designed the application for a web-based balaraja housing information system. This system is used to facilitate the process of sales, promotions and detailed information about balaraja housing, where marketing can enter home listings entrusted by customers to the website of PT Indah Cemani Raya, Balaraja to be marketed, and the existence of an application to activate the list of home sales that have been inputted by marketing to the website. Reports produced are in the form of home data reports, home buyer reports, home marketing reports, periodic payment reports, house specifications and credit
\end{abstract}


simulations. Currently there is no system to facilitate customers in seeing housing products and also place an order without having to come to the location. The purpose of writing this journal is to analyze and design a sales system at PT Indah Cemani Raya, Balaraja so that it can help the parties involved in the data collection process, especially in the home sales process. PT Indah Cemani Raya, Balaraja is a private company engaged in the property business, specifically in the sale of housing construction (developers) which helps the government in increasing national economic development.

Keywords: Information Systems, Company Reports, Home Sales

\section{Pendahuluan}

Pembangunan kota dan kawasan perkantoran terus berkembang mengikuti daya tarik aktivitas perkantoran dan tuntutan kehidupan yang semakin tinggi. Daya tarik aktivitas perkantoran dan tuntutan kehidupan yang semakin tinggi ini akan selalu menarik pergerakkan penduduk dari kawaan sekitarnya maupun kawasan pendesaanuntuk berpindah dan berakaktivitas di kawasan perkotaan.

Adanya peningkatan pertumbuhan penduduk dan aktivitas di perkotaan akan memicu bertambahnya luas kawasan perkotaan secara menerus dan menekan ruang penyangga maupun ruang produktif.

Pembangunan perumahan dan pemukiman merupakan program yang membutuhkan dukungan lintas sektor, bersifat lintas wilayah (value-chain produk perumahan), memenuhi slah satu kebutuhan dasar kehidupan manusia sekaligus untuk meningkatkan mutu lingkungan kehidupan, memberi arah pada pertumbuhan wilayah, memperluas lapan kerja serta menggerakkan roda kegiatan ekonomi dalam rangka peningkatan dan pemerataan kesejahteraan rakyat.

Laju pertumbuhan penduduk di Kabupaten Tangerang yang tinggi menyebabkan kebutuhan akan rumah tinggal terus bertambah. Faktor lain yang mendorong timbulnya permintaan akan perumahan adalah posisi Kabupaten Tangerang yang cukup strategis sebagai kawasan penunjang bagi DKI Jakarta. Tangerang dan Bekasi adalah sektor yang banyak berkembang sebagai pemukiman karena harga tanah yang relatif lebih murah serta adanya transportasi yang melalui Kereta Api dan Bus.

Dalam rangka mewujudkan hal tersebut diatas, kami ingin berpatisipasi mensukseskan program pemerintah dalam hal mencukupi kebutuhan papan/perumahan bagi masyarakat prasejahtera khususnya para keluarga yang belum memiliki tempat tinggal. Memperhatikan pertumbuhan ekonomi Kabupaten Tangerang yang cukup pesat mendorong kami untuk membangun sustu perumahan yang sehat (RSH) lengkap dengan sarana yang layak sesuai dengan tuntutan kehidupan pribadi yang modern.

\subsection{Literatur Review}

Pada langkah ini penulis mempelajari topik dan permasalahan yang berhubungan dengan sistem informasi serta pencarian landasan-landasan teori yang diperoleh dari berbagai buku dan juga internet untuk melengkapi pembendaharaan konsep dan teori sehingga memiliki landasan dan keilmuan yang baik. Hal ini dilakukan untuk mendapatkan pemahaman tentang konsep perancangan Sistem Informasi Penjualan Rumah PT. Indah Cemani Raya. Output yang dihasilkan yaitu Pemahaman tentang teori dan konsep

\subsection{Tujuan Penelitian}

Tujuan penelitian ini adalah merancang dan membangun sebuah sistem informasi penjualan yang mempermudah perusahaan dalam penyebarluasan informasi dan promosi, serta membantu perusahaan konsumen dalam layanan transaksi penjualan jarak jauh sehingga membantu perusahaan dalam memperluas wilayah pemasaran. 


\subsection{Solusi atau Ide}

Sistem Informasi Penjualan Rumah yang dibuat ini meliputi :

a. Pembuatan sistem Penjualan ini, hanya berisi hal yang berkaitan dengan Promosi, Pembelian serta Booking Rumah.

b. Program yang dibuat dan dapat dipergunakan pada PT Indah Cemani Raya, Balaraja.

\subsection{Kerangka kerja penelitian}

Kerangka ini berfungi sebagai pedoman atau alur penelitian, guna menuntun proses penelitian agar tidak keluar dari luar lingkup dan tercapainya hasil yang diharapkan. Kerangka kerja penelitian yang diterapkan oleh penulis sebagai berikut :

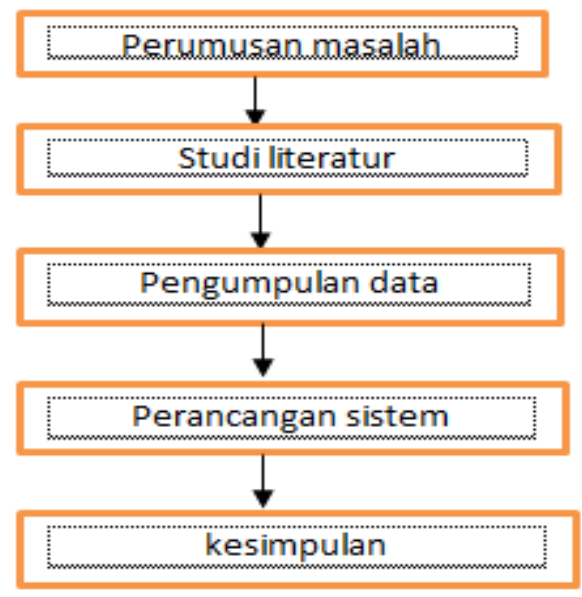

Gambar 1. Kerangka kerja penelitian

a) Perumusan masalah

Rumusan masalah dalam sebuah proposal penelitian adalah hal yang mendasar. Rumusan masalah akan menjadi penentu apa bahasan yang akan dilakukan dalam penelitian tersebut. Pertanyaan-pertanyaan yang di ajukan dalam perumusan masalah, kemudian akan di jawab dalam proses penelitian dan tertuang secara sistematis dalam laporan penelitian. Semua bahasan dalam laporan penelitian, termasuk juga semua bahasan mengenai kerangka teori dan metodologi yang digunakan, semuanya mengacu pada perumusan masalah. Oleh karena itu, ia menjadi titik sentral. Disinilah fokus utama yang akan menentukan arah penelitian (Yenrizal, 2012).

b) Studi literatur

Penelitian dengan studi literatur adalah penelitian yang persiapannya sama dengan penelitian lainnya akan tetapi sumber dan metode pengumpilan data di pustaka, membaca, memcatat, dan mengelolah bahan penelitian.

c) Pengumpulan data

Pengumpulan data adalah aktivitas mencari data yang di butuhkan dalam rangka mencapai tujuan penelitian sosial. Data adalah bahan keterangan berupa himpunan fakta, angka, huruf, grafik, tabel, lambang, objek, kondisi, situasi. Data merupakan bahan baku informasi.

d) Perancangan sistem

Perancangan sistem adalah merancang atau mendesain suatu sistem yang baik yang isinya adalah langkah-langkah operasi dalam proses pengolahan data dan proses prosedur-prosedur untuk mendukung operasi sistem.

2. Metode penelitian 
Penelitian ini dilaksanakan di PT. Indah Cemani Raya, Balaraja. Penelitian dilakukan dalam rangka pembangunan sistem informasi penjualan rumah tersebut. Penelitian diawali dengan mengindentifikasi layanan pada perusahaan yang didapatkan dari hasil interview dengan karyawan dan analisis proses yang ada didalamnya. Metode yang digunakan untuk penelitian ini adalah sebagai berikut :

a) Observasi

Pengamatan yang dilakukan secara sengaja dan sistematis untuk kemudian dilakukan pencatatan dan mempelajari unsur-unsur yang tampak dalam suatu gejala gejala dalam objek di tempat penelitian.

b) Wawancara

Yaitu dengan menanyakan atau tanya jawab yang berkaitan dengan permasalahan yang terjadi dalam pengolahan yang berhubungan langsung dan berdasarkan pada tujuan penelitian

c) Studi Pustaka

Yaitu dengan mengumpulkan berbagai sumber sumber refrensi baik berupa bukubuku, jurnal dan yang lainnya yang sesuai dengan permasalahan penulis, sebagai bahan pertimbangan untuk mendapakan data sekunder yang dapat menunjang penyusun dalam menganalisis.

Berdasarkan proses yang ada didalam PT Indah Cemani Raya, Balaraja. dilakukan perancangan sistem informasi dengan menggunakan metode waterfall yang terdiri dari : Identifikasi Kebutuhan, Perancangan Sistem Informasi, Implementasi, Testing, dan Maintenance.

\subsection{Metode pengumpulan data}

Analisa data merupakan salah satu langkah penting dalam memperoleh temuantemuan hasil penelitian. Hal ini, disebabkan data akan menentukan kita ke arah temuan ilmiah, bila di analisis dengan teknik-teknik yang tepat, analisa sistem dilakukan dengan Metode Analisa SWOT, yaitu kekuatan (Strengths), kelemahan (Weaknees), kesempatan (Oppurtunities), dan yang menjadi ancaman (Threats). Analisa SWOT dapat diterapkan dengan menganalisis dan memilih berbagai hal yang mempengaruhi keempat faktornya, kemudian menerapkannya dalam gambar matrik SWOT dengan menggunakan pendekatan pemecahan masalah menggunakan konsep service marketing mix (bauran pemasaran jasa) 7 p-product, price, promotion, place, people, process, dan physical envidence.

Perimbangan penetapan lokasi

\section{Kekuatan (Strengths)}

a) Customer sudah siap

b) Target market kalangan menengah kebawah

c) Harga jual unit rumah relatif terjangkau

d) Esuai rencana tata ruang wilayah Kabupaten Tangerang

e) Harga tanah relatif murah

f) Lokasi sangat strategis, dekat dengan fasilitas umum (Sarana pendidikan, Transportasi 24 jam, Sarana pemerintah dll).

g) Bebas banjir

\section{Kelemahan (Weakness)}

Jumlah pemilik relatif banyak, tetapi semua pemilik sudah sepakat tanahnya untuk dibebaskan.

\section{kesempatan (Oppurtunities)}

a) Masih sedikit perumahan terpadu di lokasi

b) Dekat dengan fasilitas pendidikan 
c) Transportasi mudah

d) Dekat dengan aktifititas masyarakat (Kantor Pemerintahan, Pusat pembelanjaan dll)

e) Dekat dengan pusat belanja Tangerang

f) Harga tanah relatif murah

g) Data pemilik lengkap

\section{Ancaman (Threats)}

a) Perkembangan kompetitor perumahan

b) Lokasi menjadi incaran investor / Spekulan tanah

\subsection{Metode pengembangan sistem}

Metode waterfall adalah metode yang menyatakan sebuah pendekatan yang sistematis dan sekuensial melalui tahapan-tahapan yang ada untuk membangun sebuah perangkat lunak. Penulis menggunakan model waterfall, dikarenakan metode ini menekan pada sebuah ke-terurutan dalam proses pengembangan perangkat lunak[12].

\section{Hasil dan pembahasan}

\subsection{Analisa Sistem yang Berjalan}

Analisis sistem merupakan penguraian sistem informasi yang sedang bejalan secara utuh kedalam bagian-bagian komponennya dengan maksud untuk mengidentifukasi dan mengevaluasi permasalahan-permasalahan, hambatan hambatan dan kebutuhankebutuhan yang diharapkan, sehingga dapan diusulkan solusi yang diusulkan dan kebaikan-kebaikannya.

Kegiatan analisis sistem yang berjalan dengan menggunakan analisis sistem yang berorientasi pada objek-objek sangat diperlukan oleh sistem yang akan dirancang. Dengan maksud untuk menitikberatkan kepada fungsionalitas sistem yang berjalan dengan tidak terlalu menitikberatkan pada alur proses dari sistem. Selanjutnya dari hasil analisis ini divisualisasi dan didokumentasi dengan perancangan Unified Modeling Language (UML). Pertimbangan dari diagram ini dapat mewakili secara keseluruhan sistem yang berjalan yang dapat dimengerti oleh user.

Berikut flowchart dokumen dari sistem berjalan : 


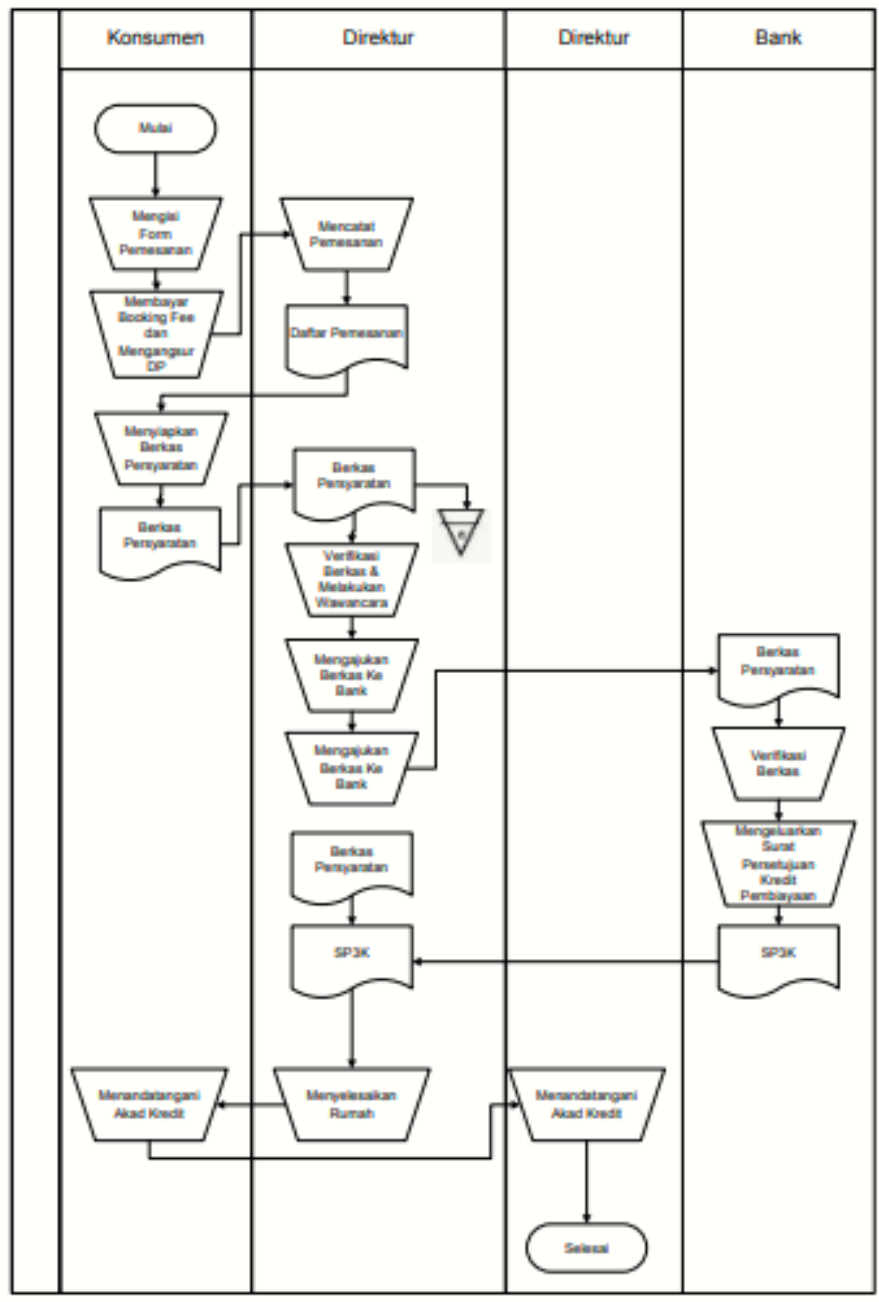

Gambar 4.1 Flowchart Dokumen Sistem Berjalan

\subsection{Kelemahan dan Kelebihan Sistem yang Berjalan}

\subsubsection{Kelemahan}

Berdasarkan hasil penelitian yang penulis lakukan terhadap sistem yang berjalan, maka terdapat beberapa kelemahan sistem yang sedang berjalan, antara lain :
a) Kemampuan mengakses data
b) Kurangnya Informasi yang dapat diakses public
c) Tidak ada Simulasi Kredit
d) Rekapitulasi yang lambat
e) Untuk merekap semua data secara manual akan memakan waktu yang cukup lama.

\subsubsection{Kelebihan}

Mudah di pelajari dalam hal pengunaannya Mampu menghasilkan informasi yang berupa laporan, jumlah penjualan rumah yang di terima masuk dan data konsumen.

\subsubsection{Definisi Aktor dan Use Case}

Berdasarkan asumsi-asumsi yang digunakan dapat didefinisikan aktor dan Use Case yang berperan, yaitu pada tabel berikut :

Tabel 3.3 Definisi Aktor 


\begin{tabular}{|c|c|c|}
\hline $\mathrm{NO}$ & Aktor & Deskripsi \\
\hline 1. & Admin & $\begin{array}{l}\text { Admin bertugas untuk: } \\
\text { 1. Mengelola data admin : menambah, mengubah dan } \\
\text { menghapus data admin. } \\
\text { 2. Simulasi Kredit } \\
\text { 3. Mengelola data konsumen : menambah, mengubah } \\
\text { dan menghapus data konsumen. } \\
\text { 4. Mengelola data rumah : menambah, mengubah dan } \\
\text { menghapus data rumah. } \\
\text { 5. Mengelola data pemesanan : menambah, mengubah } \\
\text { dan menghapus data pemesanan. } \\
\text { 6. Mengelola data penjualan : menambah, mengubah } \\
\text { dan menghapus data penjualan. } \\
\text { 7. Mengelola data angsuran : menambah, mengubah } \\
\text { dan menghapus data angsuran. } \\
\text { 8. Mengelola data pembayaran kelebihan tanah : } \\
\text { menambah, mengubah dan menghapus data } \\
\text { pembayaran kelebihan tanah. } \\
\text { 9. Mengelola data pembayaran tambah pondasi : } \\
\text { menambah, mengubah dan menghapus data } \\
\text { pembayaran tambah pondasi. } \\
\text { 10.Cetak Laporan. }\end{array}$ \\
\hline 2. & $\begin{array}{l}\text { Pengunjung } \\
\text { Website }\end{array}$ & $\begin{array}{l}\text { 1. Lihat Spesifiaksi Rumah } \\
\text { 2. Lihat Ketersediaan Rumah } \\
\text { 3. Lihat Informasi Perusahaan } \\
\text { 4. Simulasi Kredit }\end{array}$ \\
\hline 3. & Direktur & Dapat melihat laporan. \\
\hline
\end{tabular}

\subsection{Penggambaran Sistem Usulan \\ 3.3.1 Desain Antarmuka}

\section{Tampilan Login Admin}

Tampilan ini menjelaskan Tentang menu awal website penjualan rumah PT Indah Cemani Raya, Balaraja. pada halaman login ini berfungsi untuk masuk kedalam sistem informasi penjualan rumah yang terdapat inputan berupa username,password dan tombol login. Berikut tampilan halaman login seperti gambar 3.3.1 dibawah ini : 


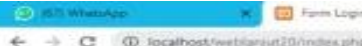

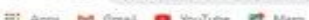
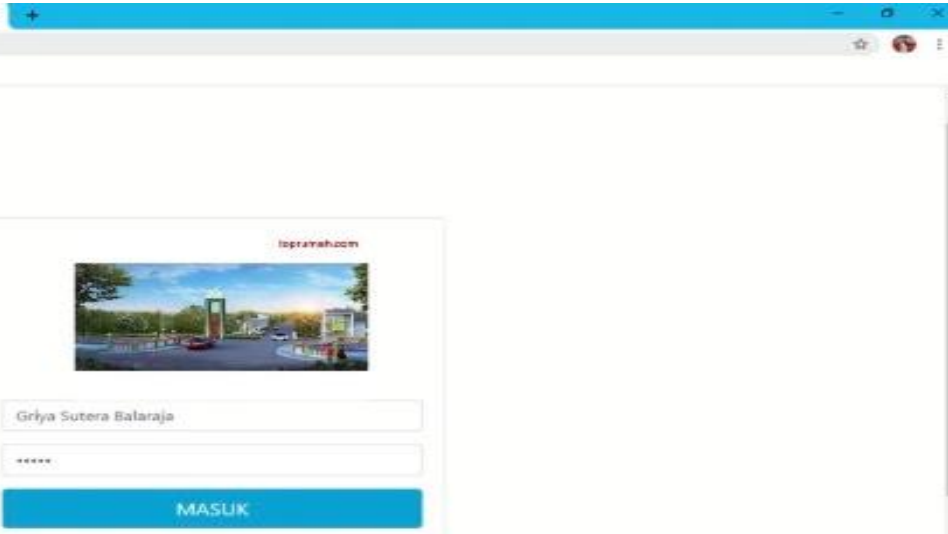

\#

Gambar 3.3.1 Halaman Login Admin

Tampilan Menu Utama Website

Tampilan ini menjelaskan tentang menu home yang berfungsi untuk menampilkan halaman awal web pada sistem informasi perumahan rumah. Berikut ini adalah tampilan halaman menu home :

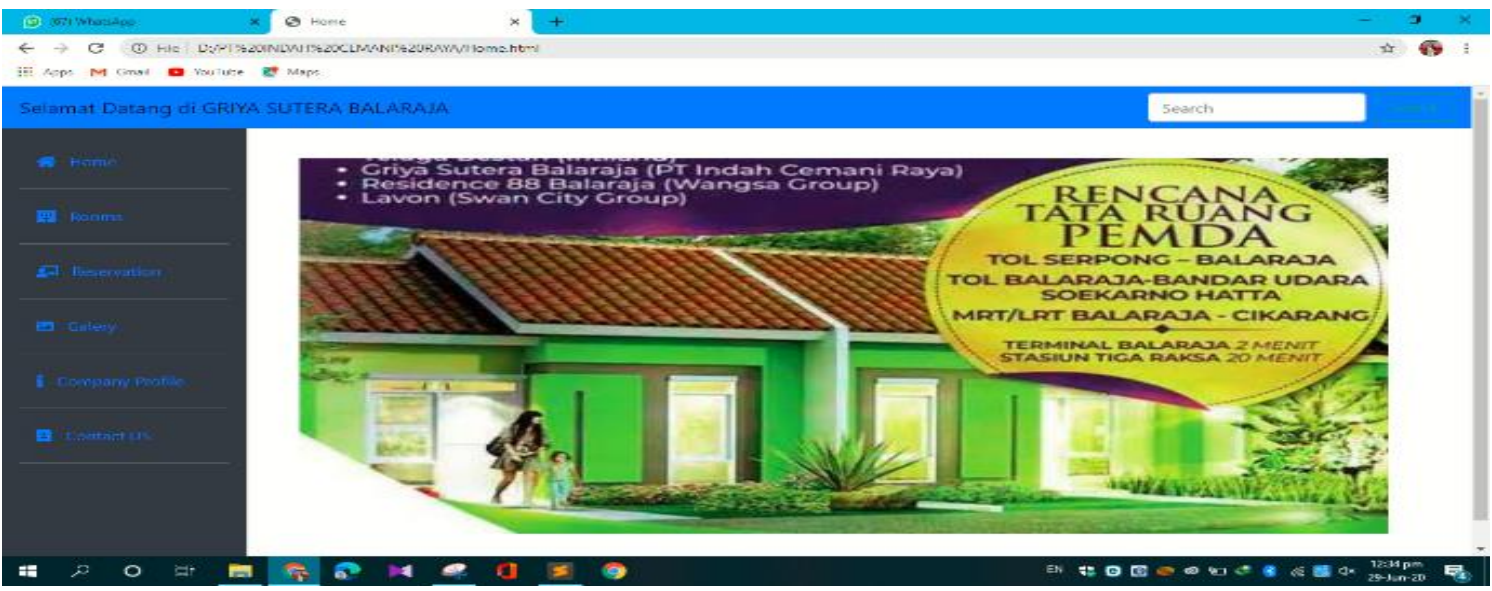

Gambar 3.3.2 Menu Utama Website

Tampilan Data Konsumen

Tampilan ini menjelaskan tentang menu Data konsumen yang berfungsi untuk menampilkan data pelanggan dari masyarakat. Berikut penginputan yang berada didalam menu data konsumen yaitu Nama, NIK. alamat. pekerjaan. Berikut tampilan halaman data konsumen seperti Gambar 3.3.3 dibawah ini : 


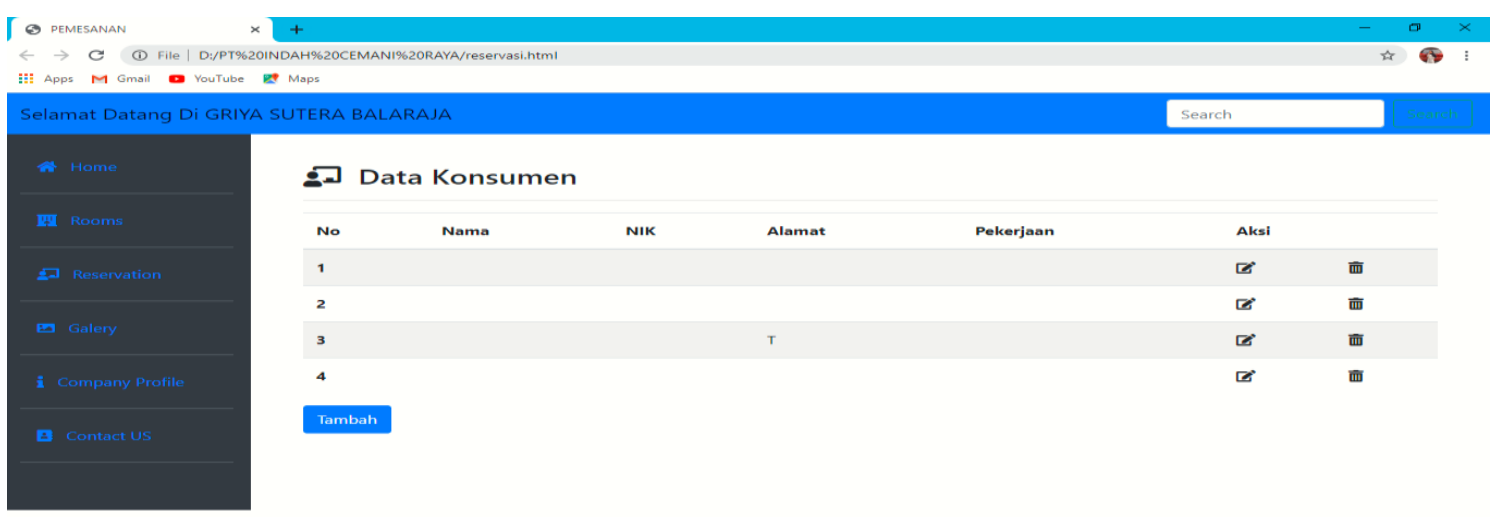

\section{Gambar 3.3.3 Tampilan Data Konsumen}

Halaman Informasi Perusahaan

Tampilan ini menjelaskan tentang menu informasi perusahan PT Indah Cemani Raya, Balaraja. yang terdiri dari Spesifikasi rumah, peta Map. Berikut tampilan halaman informasi perusahaan seperti Gambar 3.3.4 dibawah ini :

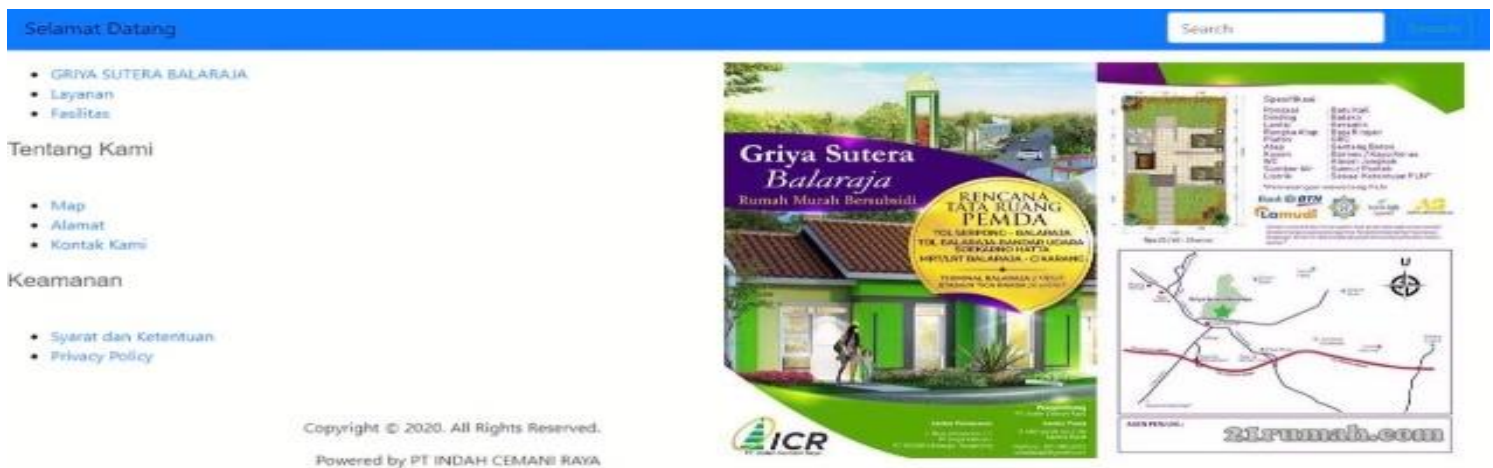

Gambar 3.3.4 Halaman Informasi Perusahaan

Tampilan Menu Booking

Tampilan ini menjelaskan tentang halaman menu booking rumah yang berfungsi untuk melakukan pemesanan rumah yang dilakukan oleh pelanggan, pada halaman booking rumah ini mempunyai nomor booking, Nama. NIK, Nomor Telp, Type rumah. Tampilannya seperti Gambar 3.3.5 dibawah ini :

至

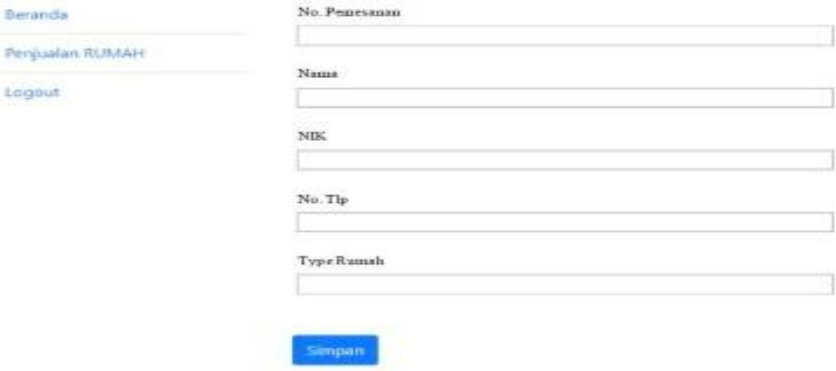




\section{Kesimpulan}

Berdasarkan analisis dan perancangan sistem informasi Penjualan Perumahan yang dilakukan pada PT Indah Cemani Raya, Balaraja. maka dapat ditarik kesimpulan saran sebagai berikut :

1. Berdasarkan analisis terhadap manajemen pada PT Indah Cemani Raya, Balaraja. kegiatannya belum didukung sepenuhnya oleh pemanfaatan sistem informasi / teknologi informasi yang memadai.

2. Pemanfaatan dan pengembangan sistem informasi penjualan pada PT Indah Cemani Raya, Balaraja. belum optimal, hal ini terkait dari banyaknya fungsi pengolahan data pembeli dan data penjualan yang belum terintegrasi dengan komputer.

3. Sistem informasi penjualan perumahan ini memiliki beberapa kelebihan yaitu mampu menyajikan seluruh data penjualan dengan cepat, laporan penjualan yang dihasilkan lengkap dan akurat, untuk tampilan memberikan kesan minimalis dan sederhana sehingga pengguna baik dari internal maupun eksternal perusahaan dapat dengan mudah mencari data properti.

4. Sistem informasi Penjualan Perumahan Pada PT Indah Cemani Raya, Balaraja. memudahkan pembeli melihat produk perumahan tanpa harus mendatangi tempat perumahan. Sistem informasi penjualan Rumah Griya sutera balaraja mempermudah dalam proses pemesanan rumah.

\section{Saran}

Setelah melakukan penelitian terhadap Sistem Informasi Penjualan Perumahan Pada PT Indah Cemani Raya, Balaraja. dapat memberikan beberapa saran sebagai berikut :

1. Pengembangan fitur penjualan rumah berbasis PT Indah Cemani Raya, Balaraja.

2. Untuk dapat mendukung sistem yang telah dirancang perlunya Sumber Daya Manusia dan fasilitas yang baik untuk mendukung implementasi dari sistem agar dapat berjalan dengan baik.

\section{Daftar Pustaka}

[1] Laudon, C. Kenneth; \& P. Laudon, Jane. 2010. Management Information Systems: Managing The Digital Firm. Eleventh Edition. New Jersey, United States of America : Pearson Prentice Hall.

[2] T. Sutabri, Konsef Dasar Sistem Informasi, Yogyakarta, Andi, 2012.

[3] D. Sunyoto, Dasar-dasar Manajemen Pemasaran, Yogyakarta, Caps, 2013.

[4] M. Madcoms, Kumpas Tuntas Adobe Dreamweaver Dengan Pemrograman PHP \& MySQL, Yogyakarta, Andi Offset, 2013.

[5] B. Nugroho, Aplikasi Pemrograman Web Dinamis Dengan PHP dan MySQL, Yogyakarta, Gava Media, 2011.

[6] Masruri Hilmi, 2015, "Membangun SMS Gateway dengan Gammu \& Kalkun", Elex Media Komputindo, Jakarta.

[7] Kadir A, 2014, Pengenalan Sistem Informasi Edisi Revisi, Penerbit Andi, Yogyakarta

[8] Sugianto. 2013, Sistem Informasi Pemasaran PT. Citra Graha Cemerlang 
[9] Sutarman, 2007, Membangun Aplikasi Web dengan PHP dan MySQL, Graha Ilmu, Yogyakarta

[10] Eka,. P. I Putu Agus, "Sistem Informasi dan Implementasinya" No ed, Bandung : Informatika, 2014.

[11] T. Sutabri, Konsef Dasar Sistem Informasi, Yogyakarta, Andi, 2012 